\title{
PERSPECTIVES OF USE A NEW GENERATION GRANULATED ORGANIC-MINERAL FERTILIZERS
}

Yaroslav Hotskiy, Andrii Stepaniuk

Department of Machines and Apparatus of Chemical and Oil Refinery Productions, National Technical University of Ukraine "Igor Sikorsky Kyiv Polytechnic Institute", UKRAINE, Kyiv, Polytekhnichna st. 39, Build. 19, E-mail: yaroslavgotskyi@gmail.com

The main problems of preservation and increase of soil fertility with the use of multilayer granular organic-mineral fertilizers, which contains humic organic compounds, deoxidizing impurities and mineral components are considered. The urgency of creation of new resource-saving technologies for the production granular organic-mineral fertilizers from waste of chemical, food and agrarian productions are determined.

Key words - soil fertility, organic-mineral fertilizers, resource conservation, granule.

\section{Introduction}

The strategy of sustainable development of Ukraine as a state, a significant part of the export, which is the export of agricultural products, includes the development of the agro-industrial complex, strengthening of competitiveness on the market, increase of markets for production, preservation of natural resources and protection of the environment.

Ukraine belongs to one of the leading countries in the production and sale of agricultural products, as of 2018, the share of exported vegetable agricultural products is $20,9 \%$ to the total volume of foreign trade of Ukraine, of which $15,3 \%$ is the export of grain crops [1]. The diagram of the main commodity exported products is shown in Fig. 1.

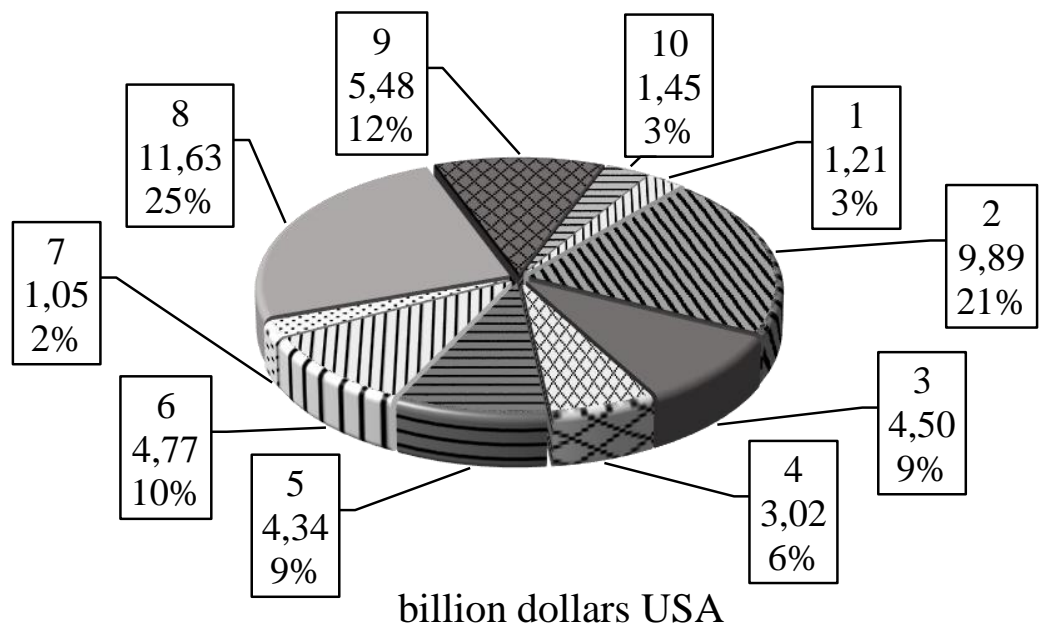

1 - livestock products; 2 - plant products; 3 - fats and oils; 4 - finished food products; 5 - mineral products; 6 - products of the chemical and allied industry; 7 - textile materials, leather and clothing; 8 - base metals; 9 - machines, equipment and machinery; 10 - other

Fig. 1 - Commodity structure of Ukraine's exports in 2018

Due to the fact that gross collections of agricultural plant products depend on soil fertility, increasing and maintaining the fertility of all available soils is one of the main strategies for economic development.

In order to meet the food and export needs in Ukraine, the agricultural area has been increased, which is approximately $53,9 \%$ of the total area of the territory [2]. Increase in soil tillage leads to deterioration of ecological balance. Therefore, in order to preserve ecological balance, it is necessary to reduce the amount of arable land to $33 \%$ of the total area of the territory, 
that is, to reduce the area of arable land by $24 \%$ or to withdraw from land use 14 million hectares of agricultural land [3].

Recently soil fertility has been rapidly decreasing because of irrational land use, soil erosion, pesticide and herbicides contamination, mineral fertilizer residues, adverse weather conditions and soil compaction when cultivated with agricultural machinery. Of the total area of about 12,9 million hectares of arable land destroyed by water and wind erosion. Annual loss of humus from soil is 1,08 tons per hectare in Ukraine in general [4]. Also very significant impact on the reduction of soil fertility have reducing the balance of nutrients, decalcification and physical degradation.

Another important scientific and technical problem is the creation of non-waste land use and reuse of waste from the food, chemical and agrarian industries as raw materials for the production of fertilizers.

\section{Main part}

Agrarians make a large amount of mineral fertilizers every year in order to maintain a stable harvest. In 2016 into the soil were introduced over 1724,4 thousand tons of mineral fertilizers, which is irrational use of mineral resources [4]. Excessive use of mineral fertilizers leads to an increase in the concentration of mineral salts in the soil, resulting in the destruction of the structure of the soil, in the vegetables accumulate harmful to health of nitrates and phosphates, erosion of water-soluble components of fertilizers and their entry into groundwater and reservoirs [3].

Application of mineral fertilizers has a number of shortcomings, but the complete refusal of their use is also undesirable, as the termination of their application will lead to a decrease in plant yield due to lack of plants essential for the normal development and functioning of such important substances as nitrogen, phosphorus, and potassium. To solve this problem is the use of complex granular organic-mineral fertilizers with a given composition of components in accordance with agro-climatic conditions of cultivation.

The development of agrarian industry is impossible without the improvement of available fertilizers and technology of their production. The relevance of using a new-generation fertilizers, which includes controlled and slow release fertilizers is increasing. The main reasons for this are their high efficiency compared to conventional fertilizers. Fertilizers of slow release and controlled action are fertilizers that contain plant nutrients in a form that allows them to slow down their release and absorption by the plant after application, or prolong the period of their availability in the soil.

To create these fertilizers it is necessary to determine the beneficial effect of each component, placement and concentration in the granule. It is also necessary to create technological bases for the production of fertilizers with the use of various wastes of the food, chemical and agrarian industries. Organic raw materials for the production of these types of fertilizers may be peat, brown coal, hydrolyzed lignin and other organic residues and waste from agrarian and food industries [3].

The choice of components to the granular OMF of prolonged or controlled action depends on many factors. The most important physical and chemical parameters are adhesion, aggregate state and solubility of components on which the choice of equipment and process depend on. The most important agro-climatic parameters include the regime of moisture and soil condition. For acid soils, it is possible to add to the granular fertilizer a deoxidizing component, such as lime and calcium carbonate. In conditions of arid climate and uneven rain regime in the form of integrated granular fertilizers, it is possible to add components with certain physical-chemical properties. The list of proposed useful components are shown in table 1. 
Table 1 List of proposed components and their functions in the fertilizers

\begin{tabular}{|c|l|l|}
\hline № & \multicolumn{1}{|c|}{ A useful ingredient in fertilizer } & \multicolumn{1}{c|}{ Component function } \\
\hline 1 & $\begin{array}{l}\text { Ammonium sulfate, nitrate, ammonium } \\
\text { phosphate, urea (carbamide), potassium sulfate, } \\
\text { potassium chloride }\end{array}$ & $\begin{array}{l}\text { Nutrition of plants with mineral } \\
\text { compounds N, P, K. }\end{array}$ \\
\hline 2 & $\begin{array}{l}\text { Humic components from brown coal and peat, } \\
\text { lignin, compost (bio humus), disinfected and } \\
\text { treated waste from livestock and poultry, bone } \\
\text { meal. }\end{array}$ & $\begin{array}{l}\text { Restoration of the level of humus in } \\
\text { the soil, creating a nutrient medium } \\
\text { for the propagation of useful } \\
\text { microorganisms. }\end{array}$ \\
\hline 3 & Calcium carbonate, lime & Neutralization of acid soils. \\
\hline 4 & $\begin{array}{l}\text { Gypsum. } \\
\text { Bentonite clay, zeolite, perlite. }\end{array}$ & $\begin{array}{l}\text { Neutralization of alkaline soils.. } \\
\text { washing, moisture sorption and its } \\
\text { content in the granule, prevention of } \\
\text { explosive properties of fertilizers. }\end{array}$ \\
\hline 6 & $\begin{array}{l}\text { Sulfur, phosphogypsum, phosphorous flour, peat, } \\
\text { fatty acid salts, calcium and magnesium } \\
\text { phosphates, magnesium oxide, polymers } \\
\text { (polyethylene, ethylene vinyl acetate, polyesters, } \\
\text { carbamide formaldehyde resins and others). }\end{array}$ & $\begin{array}{l}\text { The containment (encapsulation) } \\
\text { components inside the granule and } \\
\text { their controlled release, depending } \\
\text { on the soil conditions, temperature } \\
\text { and water content. }\end{array}$ \\
\hline
\end{tabular}

It is also possible to add to the granules potassium salts, chalk, phosphorous flour, phosphogypsum and many other useful components, which are usually introduced separately and will allow the plant to provide all the necessary nutrients and trace elements.

\section{Conclusion}

The main advantages of complex granular organic-mineral fertilizers are the high degree of assimilation of useful components and slow release of useful components in the soil, which is provided by the multilayer structure of granule. Application of organic-mineral fertilizers of this type allows to restore soil fertility and to dispose of it from the chemical, food and agrarian industries. In the production of these fertilizers the most important stage of production is the process of granulation, so the study of this process is an important scientific and technical task.

\section{References}

[1] State Statistics Service of Ukraine, "Commodity Pattern of Foreign Trade of Ukraine, 2018," State Statistics Service of Ukraine, 2019 [Online]. Available: http://www.ukrstat.gov.ua/operativ/operativ2018/zd/tsztt/tsztt_e/tsztt1218_e.htm [Accessed March 20, 2019].

[2] The State Service of Ukraine for Geodesy, Cartography \& Cadastre, "Zemelnyi fond Ukrainy stanom na 1 sichnia 2016 roku" The State Service of Ukraine for Geodesy, Cartography \& Cadastre, 2019 [Online]. Available: https://land.gov.ua/ [Accessed March 20, 2019].

[3] Kornienko Y. M. and Stepaniuk A. R. "Stvorennia huminovo-mineralnykh dobryv dlia zabezpechennia ekolohichnoi rivnovahy" [Creation of humic and mineral fertilizers for ecological balance], Chemical Engineering, Ecology and Resource Conservation, No. 2, pp. 48 - 52, 2008.

[4] Khodakivska O.V., Korchynska S.G and Matvienko A.P. "Ekonomichni problemy vidtvorennia rodiuchosti gruntiv" [Economic problems of reproduction of soil fertility], Bulletin of Agrarian Science, No. 12, pp. 71 - 75, 2017. 